\title{
Disasters and Domestic Tourist Arrivals in Indonesia in 2013-2017
}

\author{
Alla Asmara ${ }^{1}$, Annisa Hafizhah Uzdah ${ }^{2}$ \\ ${ }^{1}$ Department of Economics, Faculty of Economics and Management, IPB University, Jl. Agatis, IPB Dramaga, \\ Bogor 16680 \\ ${ }^{2}$ Department of Economics, Faculty of Economics and Management, IPB University, Jl. Agatis, IPB Dramaga, \\ Bogor 16680
}

Corresponding Author: Alla Asmara

\begin{abstract}
The tourism sector is the leading sector in Indonesia's economic development in the future. One of the potential demands for Indonesia tourism sector comes from domestic tourist arrivals who show an increasing trend each year. On the other hand, the number of disasters in Indonesia in the last 10 years also showed an increasing trend. Starting from this phenomenon, the purpose of this study is to analyze the impact of disasters on domestic tourist arrivals in Indonesia. The analytical method used is descriptive analysis and panel data with Fixed Effect Model (FEM) approach. In this study, natural disasters were proxied through frequency of disasters and the number of fatalities. The results of the analysis indicate that frequency of disasters and the number of fatalities have a negative effect on the domestic tourist arrivals. However, only the number of fatalities has a statistically significant effect. Economic variables which also have a significant effect on domestic tourist arrivals are GRDP/capita, CPI, population, number of hotel rooms and accessibility. All of these variables have a positive effect on domestic tourist arrivals.
\end{abstract}

Keywords: Disasters, panel data, tourism, domestic tourist JEL Classification code: Z38; O20; R58

\section{INTRODUCTION}

Tourism is one of the basic sectors that has a large multiplier effect because it is able to attract other sectors to develop. This sector becomes the leading sector of the 5 sectors of the Indonesian government's development targets in 2014-2019. The five sectors include infrastructure, maritime, energy, food and tourism. Tourism is set as the leading sector because in the short, medium and long term is predicted will have a positive growth and is considered a strategic sector and able to become a media integration program between sectors (Kemenpar 2017).

Liu and Wu's research (2019) shows that a $10 \%$ increase in tourism productivity will increase tourism added value by $4.11 \%$ and cause real GDP growth of $0.61 \%$. In addition, the tourism sector has a rapid recovery process after the financial crisis and shows outstanding performance in several countries in Europe (Dogru and Bulut 2017).

The tourism sector is seen as an important engine for economic growth and country development (Brida and Risso 2009; Tang and Tan 2013), helping to improve economic welfare for local residents (Webster and Ivanov, 2014), encouraging employment, tax revenues, investment in infrastructure, human resources and technology, encourage efficiency for local industries to compete and facilitate exploitation of economies of scale (Shahzad et al. 2017).

Domestic tourists play a large role in the development of Indonesian tourism. Although domestic tourist arrivals do not generate foreign exchange, but the 
contribution of domestic tourist has an important role in driving the economy. Domestic tourists are able to encourage the transportation sector, hotels, food and beverage provider businesses, creative industries, and so on (Kemenpar 2017). When compared to foreign tourists, domestic tourist arrivals are 19 times larger than foreign tourists in 2017 (Figure 1). Based on the research of $\mathrm{Liu}$ and $\mathrm{Wu}$ (2019), when the productivity of the tourism sector increases, it will increase domestic tourist consumption which is greater than the consumption of foreign tourists.

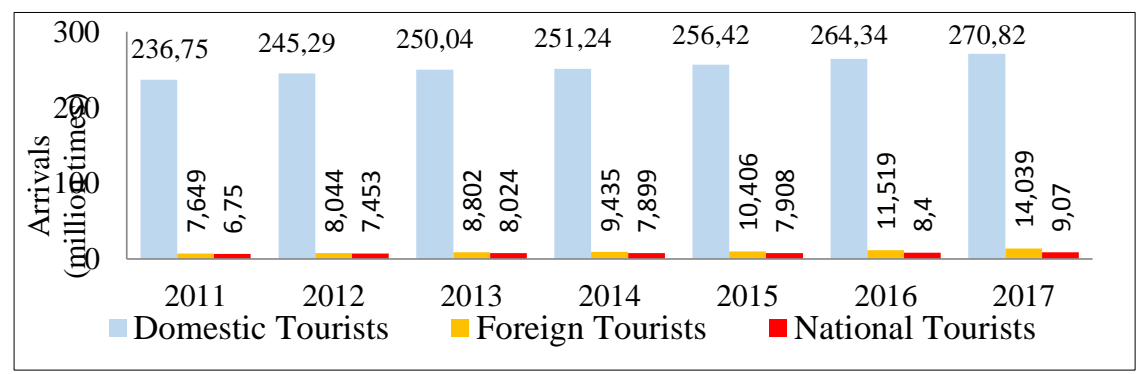

Source : Ministry of Tourism 2017

Figure 1 The number of arrivals for domestic, foreign and national tourists 2011-2017 (million times)

The domestic tourist arrivals have increased considerably each year (Figure 1). These tourists come from 33 provinces in Indonesia and travel to other regions or provinces. The number of domestic tourist arrivals in 2017 was 270.82 million trips. This number has increased by $2.45 \%$ compared to 2016, which amounted to 264.34 million. This increase was allegedly due to the improving economic conditions, conducive security, easier accessibility to tourist destinations and rapid advances in information technology (Kemenpar 2017).

The tourism industry is vulnerable to several types of crises and disasters (Cro and Martins 2017). The tourism industry is an industry that is vulnerable to shocks, one of which is a natural disaster because this industry is based on perceptions of safety, infrastructure functions and visiting mobility (Laws and Prideaux 2005; Ritchie 2008). This causes an area safety factor becomes an important consideration when deciding to travel. If the area is safe to visit, the number of domestic tourist will increase. Likewise vice versa, if the area is not safe due to natural disasters, acts of terrorism, and others, the number of domestic tourists will decrease.
According to Masinde and Buigut (2018), fatalities due to terrorist attacks have a negative impact on tourist visits in Kenya. Terrorism also has a negative impact on tourist destinations in Greece (Samitas et al. 2018). This is also supported by $\mathrm{Vu}$ et al. (2017) where a tornado disaster will cause a decrease in tourist visits both in the short and long term. The spread of SARS and avian flu in 2003 caused a decline in tourist visits in China, Hong Kong, Singapore, Japan, Taiwan and Vietnam; the tsunami on 2004 in the Indian Ocean had a negative effect on tourism industry in Maldives, Sri Lanka, Thailand and Indonesia; Bali bomb attack also caused declining tourism performance (Cro and Martins 2017). Decreasing the number of tourists will hamper local economic growth because tourism receipt comes from the tourists' expenditure.

The disaster frequency in Indonesia is increasing every year (Figure 2). In 2002, the frequency of disasters occurred at 190, while in 2018 it increased to 3399 disasters. Natural disasters still dominate in Indonesia while non-natural disasters and social disasters are relatively small. Natural disasters consist of several types of events 
such as flood, tornado, earthquake, tsunami, landslide, drought, forest fire, volcanic eruption, and tidal wave. Non-natural and social disasters have a relatively small frequency. Non-natural disasters consist of fire, transportation accident, and industrial impact. Social disasters consist of social conflict /riot and terrorism.

Increasing of frequency and intensity of natural disasters in recent years has led to the importance of tourists' post-disaster behavior understanding. It aims to improve the plan and preparation strategies so that it is expected to be able to improve postdisaster response and recovery process $(\mathrm{Wu}$ and Walters 2016).

Research by Wu and Walters (2016) showed that tourists' decision to visit a postdisaster place depends on the purpose of the visit, income and previous visiting experience. For high-income business travelers and frequent visitors, the disaster does not affect their decision to visit. This will be different from lower middle-income tourists and the purpose of the visit just for vacation, then disasters will affect their perception to delay or cancel trips to an area.

The greater of disaster frequency that occur in an area, that area is categorized as an unsafe area. This becomes a consideration for domestic tourist to visit the region. Even though the disaster has a relatively small impact. This will disrupt the travel mobility and reduce the level of tourist satisfaction and the decision to revisit the region.

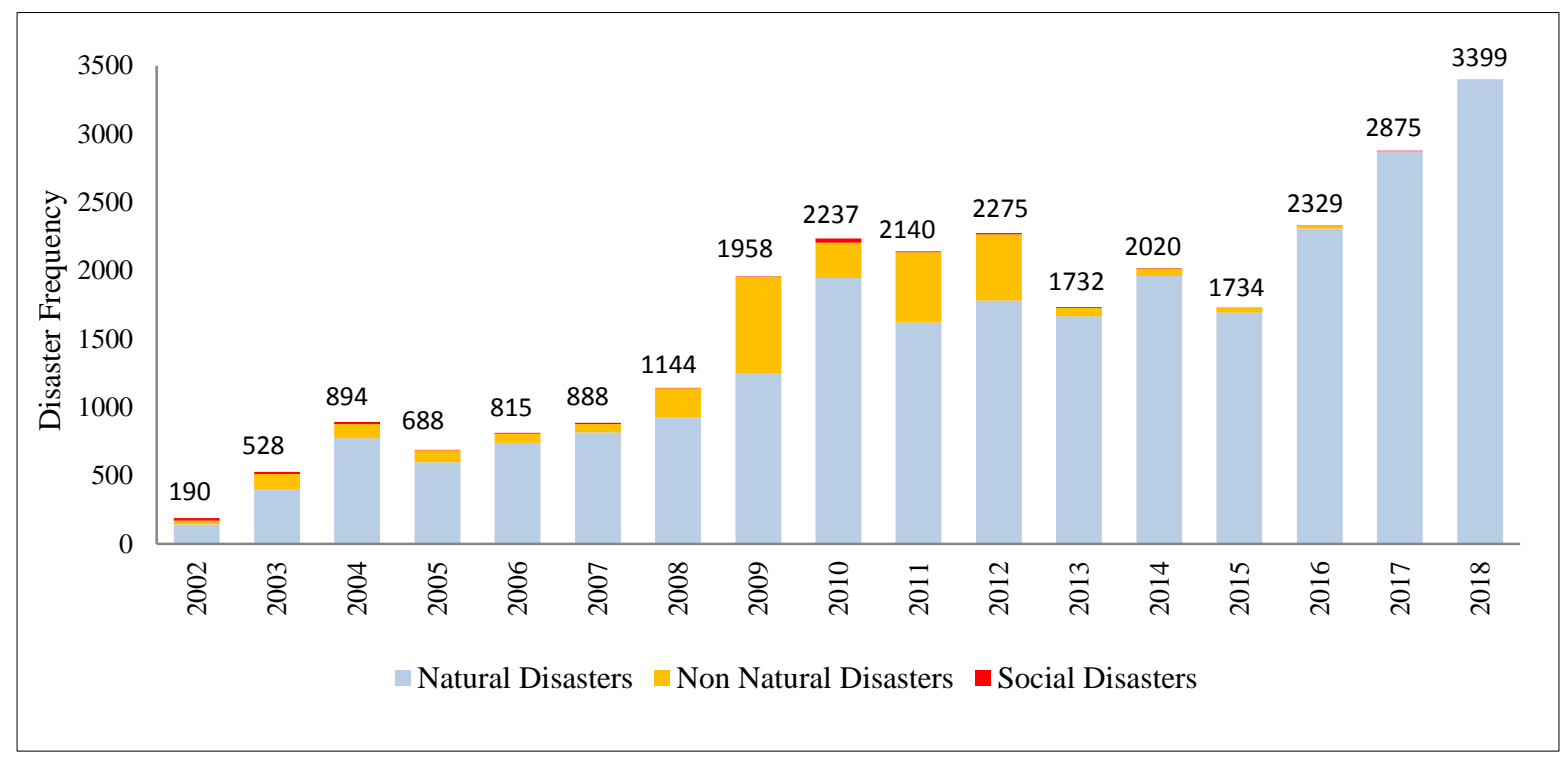

Source : BNBP 2019

Figure 2. Total disasters based on time in Indonesia from 2002-2018

According to Skidmore and Toya (2007) research, countries with higher GDP/capita, good education system, good level of openness and good infrastructure will experience smaller disaster damage. This means that developed countries will be less affected than developing countries. This smaller damage is caused by high awareness of disasters, physical infrastructure and good human resources so as to reduce disaster damage. This is also supported by Guo et al. (2015) research where disasters have a positive impact on regional economic growth in China due to the suppression of good physical infrastructure, laws and regulations, and general disasters education and prevention since 1991. Education can also increase public awareness, necessary to help them the right actions when a natural disaster occurs (Padli, Ahmat and Nawawi 2019).

Media has a considerable influence in shaping people's perceptions of the region after a disaster. One of the keys to manage 
the destination recovery by restoring the image and reputation of destinations that can be obtained by media reports (Khazai, Mahdavian and Platt 2018).

There are not many studies on the impact of disasters on domestic tourist arrivals in Indonesia. Even though the tourism sector has an important role in regional economic growth. If this sector is disrupted, it will hamper regional economic growth. Therefore, it is very important to identify factors that have a potential effect to reduce domestic tourist arrivals. Tourism income comes from tourist's expenditure. The more tourist visiting, the more the region will grow. Based on the background described, the objectives of this study are as follows: (1) describe disasters and Indonesian tourism generally; (2) analyzing the impact of disasters on domestic tourist arrivals in 33 provinces of Indonesia.

\section{LITERATURE REVIEW}

$\mathrm{Vu}$ et al. (2017) conducted research on The Interaction of Tourism and Cyclone Activity in East Asia: Sustainability and Disasters using panel data. This research uses data from 8 Southeast Asian countries and 3 East Asian countries affected by tornadoes from 1995 to 2014. Eight Southeast Asian countries affected by tornadoes are Cambodia, Indonesia, Laos, Malaysia, Myanmar, Philippines, Thailand, and Vietnam. Three East Asian countries namely China, Japan and Korea. This study used 3 models with different dependent variables, but only one model is used as a reference. The dependent variable used is the ratio of tourist arrivals. The independent variables used were damage index, GDP/capita, exchange rate, and infrastructure. The results showed that the damage index in the short and long term had a significant and negative effect on the ratio of tourist visits. The variable GDP/capita, exchange rate and infrastructure in the short term have a significant and positive effect on the ratio of tourist visits.

Guo et al. (2015) conducted research on Natural Disasters, Economic Growth and
Sustainable Development in China - An Empirical Study Using Provincial Panel Data. This study used data from 30 provinces in China from 1985 to 2011. There are 4 models used in this study, but only one model is used as a reference. The dependent variable used is GDP/capita growth. The independent variables used are the level of natural disasters, investment growth, education level, level of economic openness, and number of industries. The results showed the level of natural disasters was not significant and positive to GDP/capita growth. Investment growth and education level have a significant and positive effect on GDP/ capita growth. The level of economic openness and the number of industries had insignificant and negative effects in the first period. In the second period, the level of economic openness and the number of industries had a significant effect. The level of economic openness has a positive effect, while the number of industries has a negative effect.

Masinde et al. (2018) conducted research on the Effect of Terrorism and Travel Warning on Kenyan Tourism Demand using dynamic data panel. This study used data from 22 countries visiting Kenya in 2010 to 2015. The dependent variable used is the arrival of foreign tourists. The independent variables used were foreign tourist arrivals in the previous year, GDP/capita, the number of victims killed, travel warnings, and prices. The death victim is an approach to terrorism. The number of tourist arrivals the year before, GDP per capita and prices were not significant. The variable number of deaths and travel warnings has a significant and negative effect on the number of foreign tourist arrivals.

Hafiz et al. (2010) conducted research on trade and tourism demand in Malaysia using panel data and gravity models. This study uses Asian countries from 1997 to 2008. The dependent variable used is the number of foreign tourist arrivals. The independent variables used are GDP, relative prices, bilateral trade, total 
population, and geographical distance. The results of this study indicate that the Gross Domestic Product of origin country, the total population of origin country and the bilateral relations between the two countries have a positive relationship with the number of foreign tourist arrivals in Malaysia. Relative prices and geographical distance have a negative relationship to the number of foreign tourist arrivals in Malaysia. This means that Malaysian tourism demand has a negative elasticity

Kusni et al. (2013) conducted a study on Malaysian international tourism demand from OECD countries. This study uses panel data methods from 1995 to 2009 . The dependent variable used is the number of foreign tourist arrivals. The independent variables used are relative prices, income/capita, substitution prices in Singapore, health issues, economic crisis. The results showed that the relative price and the price of substitution in Singapore were positively related to the number of foreign tourist arrivals. The relative prices indicate that tourism demand in Singapore is inelastic because its value is less than 1 . Positive sign on the price of substitution in
Singapore shows that if there is an increase in tourism prices in Singapore, the number of foreign tourist arrivals in Malaysia will increase. In addition, per capita income and health issues are negatively related.

\section{MATERIALS \& METHODS}

The type of data used in this study is secondary data with research period from 2013 to 2017. Data was obtained from the Indonesia Statistic Bureau (BPS), Ministry of Tourism Indonesia (Kemenpar), and the National Disaster Management Authority of The Republic of Indonesia (BNPB). The endogenous variable in this study is domestic tourist arrivals in 33 provinces in Indonesia. Exogenous variables used are the frequency of disasters, fatalities, Gross Regional Domestic Product per capita (GRDP/capita), Consumer Price Index (CPI), population, hotel rooms and accessibility. The frequency of disasters is a total disaster both natural disasters, nonnatural disasters and social disasters. The fatalities were death victims from natural disasters, non-natural disasters and social disasters.

Table 1. Description of variables and source of data

\begin{tabular}{|l|l|l|}
\hline Variable & Brief Description & $\begin{array}{l}\text { Source } \\
\text { Data }\end{array}$ \\
\hline Domestic tourist arrival (Arrival) & $\begin{array}{l}\text { The number of domestic tourist arrivals in the destination province within one } \\
\text { year both from within or from outside the province }\end{array}$ & Kemenpar \\
\hline Disaster (Disaster) & $\begin{array}{l}\text { The total number of disasters occurring in the destination province within one } \\
\text { year }\end{array}$ & BNPB \\
\hline Fatality (Fatality) & Disaster victims consist of dead victims & BNPB \\
\hline $\begin{array}{l}\text { Gross Regional Domestic Product per } \\
\text { capita (GRDP/capita) }\end{array}$ & The average population income in destination province & BPS \\
\hline Consumer Price Index (CPI) & $\begin{array}{l}\text { Total cost of goods and services purchased by consumers in destination } \\
\text { province }\end{array}$ & BPS \\
\hline Population (population) & The number of residents living in the destination province & BPS \\
\hline Hotel rooms (Room) & The number of hotel rooms in each destination province & BPS \\
\hline Accessibility (Accessibility) & Ratio of road length $(\mathrm{km})$ to area $\left(\mathrm{km}^{2}\right)$ in the destination province & BPS \\
\hline
\end{tabular}

The analytical method used in this study is quantitative analysis and descriptive analysis. Descriptive analysis is used to analyze the general description of disasters, tourism and the relationship between disasters and domestic tourist arrivals. Quantitative analysis is used to analyze the factors that influence domestic tourist arrivals in 33 provinces of Indonesia. Data processing is done with the help of Eviews 9 and Microsoft Excel program. The model used is a linear model that is transformed in natural logarithms.

$$
\begin{aligned}
& \alpha_{0}+\beta_{1} \operatorname{lnDisaster}_{\text {it }}+\beta_{2} \ln \text { Fatality }_{\text {it }}+ \\
& \text { InArrival }_{\text {it }} \quad \beta_{3} \operatorname{lnGRDP/capita}{ }_{\text {it }}+\beta_{4} \operatorname{lnCPI}_{\text {it }}+ \\
& =\quad \beta_{5} \operatorname{InPopulation}{ }_{\text {it }}+\beta_{6} \operatorname{lnRoom}_{\text {it }}+ \\
& \beta_{7} \ln A_{\text {ccessibilitys }}+\varepsilon_{\mathrm{it}}
\end{aligned}
$$

Information :

Ln Arrival, the number of domestic tourist arrivals according to destination 
provinces; lnDisaster, total disasters in destination provinces; lnFatality, dead victims due to disasters in destination provinces; lnGRDP/capita in destination provinces; ln CPI, consumer price index in destination provinces; InPopulation, population in destination provinces ; lnRoom, number of hotel rooms in destination provinces; lnAccessibility, ratio of the length of the road per area in province's destination; $\varepsilon$ error; $\alpha_{0}$ constants; $\beta_{\mathrm{n}}$ expected parameters $(\mathrm{n}=1,2, \ldots . ., 8)$; i provincial tourist destinations; $\mathrm{t}$ period of time

\section{RESULT}

\section{Analysis of Disasters and Other Economic Variables Impact on Domestic Tourist Arrivals}

The Chow Test shows that the best model is Fixed Effect Model (FEM) with a probability of 0.0000 which means reject null hypothesis. Hausman Test shows the same results as the previous test. Hausman Test shows the best model is Fixed Effect Model (FEM) with a probability of 0.0000 which means reject null hypothesis. It can be concluded from the two tests that Fixed Effect Model (FEM) model is the best model.

Table 2 Chow Test dan Hausman Test

\begin{tabular}{|l|l|l|}
\hline Best Model Test & Probability & Hypothesis Result \\
\hline Uji Chow & 0.0000 & Reject $\mathrm{H}_{0}$, then FEM \\
\hline Uji Hausman & 0.0000 & Reject $\mathrm{H}_{0}$, then FEM \\
\hline
\end{tabular}

Table 3 Estimation result of disasters and other economic variables on demand for Indonesian tourism

\begin{tabular}{|l|l|l|l|l|}
\hline Variable & Pooled Model & Random Effect Model & Fixed Effect Model & \\
\hline LN_Disaster & 0.08116 & -0.0381 & -0.02193 & \\
\hline LN_Fatality & -0.0025 & 0.02472 & -0.02839 & $* *$ \\
\hline LN_GRDP/capita & 0.15697 & 0.42509 & 2.11976 & $* *$ \\
\hline LN_CPI & -1.3574 & -1.2924 & 0.62168 & $* *$ \\
\hline LN_Population & 0.69520 & 0.83690 & 3.63242 & $* *$ \\
\hline LN_Hotelroom & 0.14090 & 0.24096 & 1.26597 & $* *$ \\
\hline LN_Accessibility & 0.3338 & 0.30265 & 0.27254 & $*$ \\
\hline C & 7.0572 & -0.8680 & -91.0740 & \\
\hline
\end{tabular}

Based on the estimation result, the frequency of disasters is not significant for domestic tourist arrivals in tourist destination provinces. Although not significant, this variable has a negative coefficient that corresponds to the initial hypothesis which is -0.02193 . This means when the frequency of disasters increases by 1 percent, it will reduce the number of tourist arrivals by 0.02193 percent. Estimation result that shows the frequency of disasters does not affect the decision of tourists to visit the province can be caused because each tourist has different preferences. In addition, disasters that mostly occur are disasters with little impact so that tourists still feel safe and comfortable.

Fatalities variable has a significant and negative effect on domestic tourist arrivals with a coefficient of -0.02839 . This shows that every increase in fatalities by 1 percent, the number of domestic tourist arrivals will decrease by 0.02839 percent. The result of this analysis is in accordance with the initial hypothesis. Fatalities show the severity of the disaster. The more victims the more dangerous the disaster. It caused the place is vulnerable to be visited so that domestic tourist arrivals will experience a decline. The estimation result is in accordance with $\mathrm{Vu}$ et al. (2017) research which shows that the tornado disaster index as a proxy for disaster severity had a significant and negative influence on tourist visits in East Asian affected countries.

The GRDP/capita variable has a significant positive effect on domestic tourist arrivals with a coefficient of 2.11976. This shows that when GRDP/capita in destination province increases by 1 percent, the number of tourist visits will increase by 2.11976 percent. The estimation result is in 
accordance with the initial estimate. The relationship between the GRDP/capita in destination province and the domestic tourist arrivals in the destination province did not affect directly. The increase in GRDP/capita in the province aims to increase the number of tourist attractions or other infrastructure that support tourism so that it will attract tourists to come.

This research is supported by Sahara (2017) study which shows that when the destination country's GDP per capita increases, reflecting the level of tourism products production also increase so this becomes an attraction for foreign tourists. Based on research by $\mathrm{Vu}$ et al. 2017, a rising standard of living due to an increase in per capita income and infrastructure will increase tourist visits. A high standard of living will increase demand for good quality tourism services and infrastructure will greatly support accessibility.

CPI has a significant and positive effect on domestic tourist arrivals with a coefficient of 0.62168 . This means that an increase in CPI 1 percent will increase tourist visits by 0.62168 percent. The result of this analysis is not in accordance with the initial hypothesis. The initial hypothesis predicts a negative relationship between CPI and domestic tourist arrivals. CPI is an approach of cost variable incurred by domestic tourists to enjoy tourism products. Limited price data for the tourism sector, causing the CPI to be chosen as the appropriate approach. The difference in analysis with the initial hypothesis indicates that the price variable is not an important consideration for domestic tourists.

Population has a significant and positive effect on domestic tourist arrivals with a coefficient of 3.61537. This means when population increase of 1 percent, the number of tourist visits will increase by 3.61537 percent. The result of this analysis is in accordance with the initial hypothesis. Population variable has the highest coefficient value compared to other variables. The population reflects the number of potential tourists. The greater population in a region, the greater potential tourist visits.

The hotel room variable has a significant and positive effect on domestic tourist arrivals with a coefficient of 1.28695. This means increasing in the number of hotel room by 1 percent will increase domestic tourist arrivals by 1,28695 percent. The result of the analysis is in accordance with the initial hypothesis. The number of hotel rooms shows tourist facilities in destination provinces to accommodate tourist visits. The more hotel rooms mean the greater potential to visits.

Based on the result, accessibility variable has a significant effect on domestic tourist arrivals. Accessibility has a positive coefficient on tourist visits, namely 0.27254 . This shows that when accessibility increases by 1 percent, it will increase the number of tourist arrivals by 0.27254 percent. The estimation result is in accordance with the initial hypothesis. This result is also supported by the study of Sun et al. (2015) which shows that increasing accessibility can increase productivity in the tourism sector.

\section{DISCUSSION}

\section{General Description of Disasters and Tourism}

Disaster trend in Indonesia is increasing every year. Based on BNPB data, in 2002 the number of disasters in Indonesia was 190 disasters. This number increased to 2875 disasters in 2017 and 3399 disasters in 2018. Indonesia is a disaster-prone country because it is located in volcanic belts and 4 tectonic plates, namely the Asia Continent Plate, the Australia Continent Plate, the Indian Ocean Plate and Pacific Ocean Plate. Those caused Indonesia is prone to volcanic eruption, earthquake, tsunami, flood and landslide.

Table 2 shows that there are 4 types of disasters that occur most during 2017 until 2018, namely floods, landslides, tornadoes and forest and land fires. Floods occurred dominantly in East and Central Java provinces. Landslides dominantly in 
Central and West Java provinces. Tornadoes and forest and land fires also dominantly in East and Central Java. Four these disasters are mostly occur in Java Island. It might become a consideration for government to develop a prevention action especially in Java.

\begin{tabular}{|c|c|c|c|c|c|}
\hline \multirow[t]{2}{*}{ Disaster Type } & \multirow[t]{2}{*}{ Province } & \multicolumn{2}{|l|}{2017} & \multicolumn{2}{|l|}{2018} \\
\hline & & Frequency & Fatality (Person) & Frequency & Fatality (Person) \\
\hline \multirow[t]{5}{*}{ Flood } & East Java & 130 & 40 & 84 & 11 \\
\hline & Central Java & 191 & 23 & 79 & 6 \\
\hline & Aceh & 53 & 6 & 74 & 0 \\
\hline & West Java & 77 & 14 & 67 & 11 \\
\hline & West Sumatra & 27 & 9 & 45 & 13 \\
\hline \multirow[t]{5}{*}{ Landslide } & Central Java & 488 & 27 & 151 & 28 \\
\hline & West Java & 124 & 16 & 119 & 49 \\
\hline & East Java & 123 & 57 & 89 & 10 \\
\hline & South Sulawesi & 11 & 8 & 17 & 2 \\
\hline & West Sumatra & 8 & 2 & 14 & 8 \\
\hline \multirow[t]{5}{*}{ Tornadoe } & Central Java & 387 & 8 & 238 & 7 \\
\hline & East Java & 134 & 8 & 143 & 8 \\
\hline & West Java & 102 & 2 & 108 & 3 \\
\hline & Aceh & 27 & 0 & 48 & 1 \\
\hline & South Sulawesi & 27 & 3 & 38 & 0 \\
\hline \multirow[t]{5}{*}{ Forest and Land Fire } & East Java & 46 & 0 & 106 & 0 \\
\hline & Central Java & 1 & 0 & 70 & 2 \\
\hline & South Kalimantan & 11 & 0 & 49 & 0 \\
\hline & Aceh & 6 & 0 & 33 & 0 \\
\hline & Riau & 4 & 0 & 27 & 0 \\
\hline
\end{tabular}

The domestic tourist growth has increased every year. The growth of domestic tourist arrivals in 2017 was 2.45 percent. While the growth of domestic tourist in 2016 was 3.09 percent. Increasing the tourist growth is an indication that economic growth is good. Domestic tourists have an enough financial and feel safe to travelling. In addition, the increasing in visits led to an increasing in expenditure of domestic tourists which resulted in economic growth in the area.

There are 5 destination provinces with the largest tourist arrivals, namely East Java, Central Java, West Java, DKI Jakarta and DI Yogyakarta. These provinces are located on Java. This might happen because Java is the most populous island in Indonesia and the center of the economy so that it has great potential in tourism development.

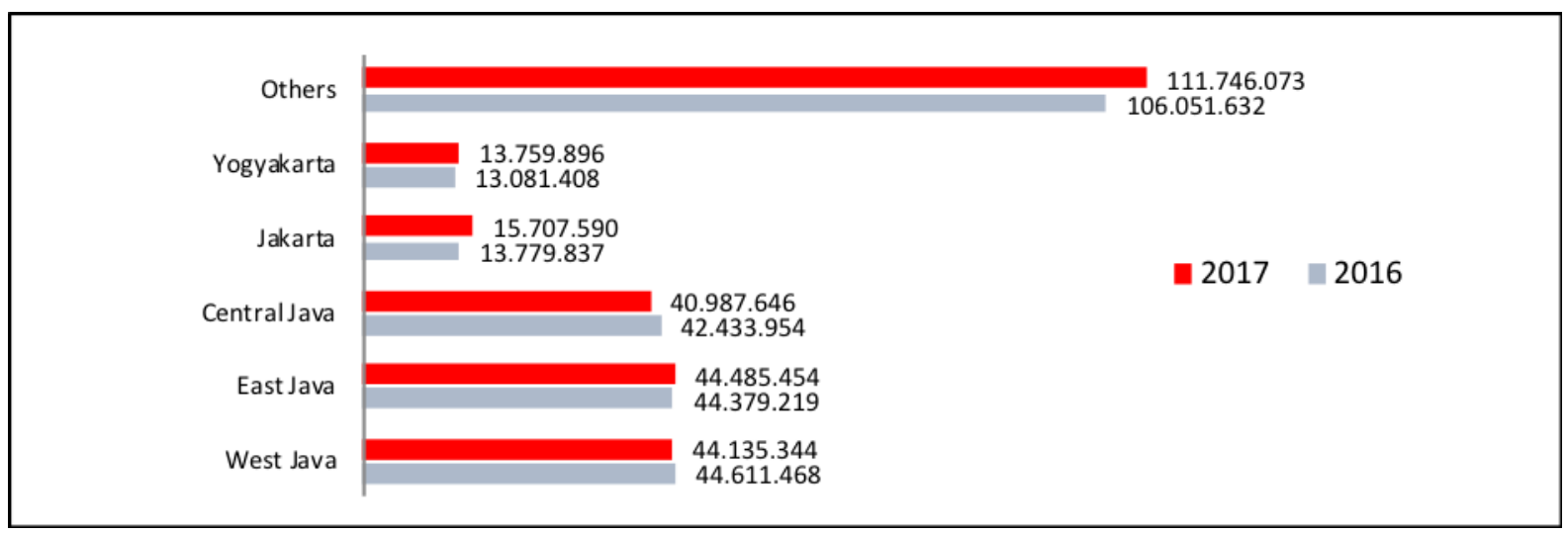

Source: Ministry of Tourism 2017

Figure 3 The number of domestic tourist arrivals according to the destination province

One of the government policies to increase tourist arrival is to set priority destinations. There are 10 places that are the focus of development, namely Lake Toba, 
Tanjung Kelayang, Tanjung Lesung, Kota Tua-Kepulauan Seribu, Borobudur, Bromo Tengger Semeru, Mandalika, Labuan Bajo, Wakatobi and Morotai. They are spread in 10 provinces in Indonesia. The purpose of establishing priority destinations is to improve the quality of tourism destinations both from accessibility, attractions and amenities.

Table 5 The growth of domestic tourist arrivals in 10 priority destination
\begin{tabular}{|l|l|l|l|}
\hline Destinations Provinces & 2016 & 2017 & Growth (\%) \\
\hline North Sumatera & 10305972 & 10579452 & 2.65 \\
\hline Bangka Belitung & 3408139 & 4060654 & 19.15 \\
\hline Banten & 8837719 & 10194827 & 15.36 \\
\hline DKI Jakarta & 13779837 & 15707590 & 13.99 \\
\hline Central Java & 42433954 & 40987646 & -3.41 \\
\hline East Java & 44379219 & 44485454 & 0.24 \\
\hline NTB & 3133118 & 4164937 & 32.93 \\
\hline NTT & 2712365 & 2784072 & 2.64 \\
\hline Southeast Sulawesi & 2760287 & 2699117 & -2.22 \\
\hline North Maluku Source: Ministry of Tourism 2017 & -3.00 \\
\hline
\end{tabular}

The success of priority destination policies can be seen from increasing visits to priority destination provinces. Table 3 shows the growth of domestic tourist arrivals in 10 priority destination provinces. West Nusa Tenggara Province experienced the largest increase in visits, namely 32.93 percent. Bangka Belitung, Banten, DKI Jakarta, North Sumatra, East Nusa Tenggara and East Java experienced positive increases. On the contrary, there are 3 provinces which experience a decrease in visits, namely Central Java, Southeast Sulawesi and North Maluku.

The biggest domestic tourist expenditure in 2016 was on domestic transportation, restaurant, hotel, non-food and souvenir industry products (Figure 4). Domestic transportation occupy the first position at 36 percent of total expenditure or 88265.44 billion rupiah. The second largest expenditure is restaurant by 23 percent or 54 702.62 billion rupiah. Furthermore, expenditures for non-food industrial products amounted to 15 percent or 36 310.52 billion rupiah. Non-food industrial products in the form of expenditures for cigarettes, fuel and shopping for personal needs such as soap, and others. Hotels and accommodations occupy the fourth position, namely 10 percent of total expenditure or 25 135.02 billion rupiah. Souvenirs occupy the fifth position of 5 percent of 11928.35 billion rupiah.

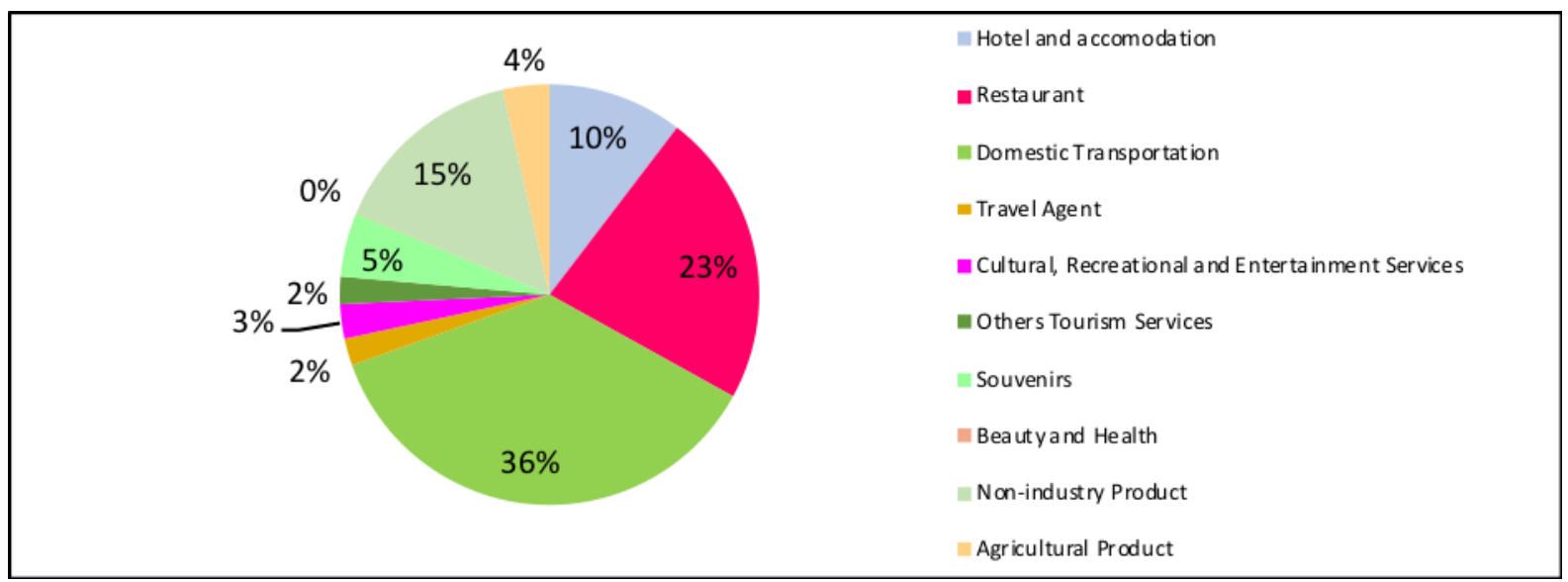

Source: Tourism Ministry 2016

Figure 4 Structure of expenditure of domestic tourists according to products of goods and services consumed in 2016

The relationship between domestic tourist arrivals and the frequency of disasters can be seen in Figure 5. The vertical line shows the average visit of 
tourists in one year and the horizontal line shows the average frequency of disasters in one year. The graph is divided into 4 quadrants namely quadrant I, quadrant II, quadrant III and quadrant IV. Quadrant I show provinces with very good tourism endurance, quadrant II shows vulnerable provinces, quadrant III shows provinces with fairly good tourism endurance, quadrant IV shows provinces with good tourism durability.

Figure 5A shows the relationship between domestic tourist visits and the frequency of disasters in 2013. Vertical lines represent the average visits of tourists in 2013, namely 3531801 visits. The horizontal line is the average frequency of disasters in 2013, which was 34 disasters. Figure 5B shows the relationship between the frequency of disasters and domestic tourist arrivals in 2017. The vertical lines represent the average visits of tourists in 2017, which were 4327830 visits. The horizontal line is the average frequency of disasters in 2017, which was 36 disasters.

In figure $5 \mathrm{~A}$, it can be seen that quadrant III had the most provinces spread. Although the provinces experienced disasters below the annual average or relatively little, but the number of domestic tourist arrivals was also small. This indicates that these provinces have not become the main destination for domestic tourists. Promotions and tourist attractions in these provinces need to be improved.

Meanwhile, provinces located in quadrant I are provinces which are the main destinations for Indonesian tourists. Although the number of disasters was high, the number of tourist arrivals was also high. This indicates that these provinces have a good tourist attraction so that they remain the main destination of Indonesian tourists. Provinces that also have good tourism attraction and are supported by relatively low frequency of disasters are provinces in quadrant IV. For provinces in quadrant II, increased promotion and attractiveness of tourism and awareness of disaster response need to be further enhanced to encourage the tourism growth in these provinces.

In 2017 (Figure 5B), there was no large shift in each quadrant. Based on the image, it was known that quadrant III still dominates, then followed quadrants I, II and IV. The number of provinces in quadrants II and III which are relatively more than quadrants I and IV indicate that increasing promotion and attractiveness of tourism in each province can be a national agenda to support the growth and development of Indonesia's tourism sector.

Table 4 describes the provinces spread in quadrants I, II, III and IV in 2013 and 2017. In 2013, quadrant I had 9 provinces namely North Sumatra Province, West Sumatra, South Sumatra, DI Yogyakarta, South Sulawesi, DKI Jakarta, West Java, Central Java, and East Java. Although the frequency of disasters is above the average, but domestic tourist arrivals remain high. In 2017, there were additional provinces into 11 provinces. Additional provinces were Aceh, Banten and South Kalimantan. Yogyakarta Province in 2017 shifted to quadrant IV because the frequency of disasters decreased.

Quadrant II in 2013 there were 6 provinces namely West Nusa Tenggara, East Nusa Tenggara, South Kalimantan, Aceh, Kep. Riau and East Kalimantan. Quadrant II shows provinces with a high frequency of disasters and low visits of domestic tourists. In 2017 it decreased to 5 provinces, namely West Nusa Tenggara, Central Kalimantan, East Kalimantan, Riau and North Sulawesi. Since 2013, the provinces of West Nusa Tenggara and East Kalimantan have not experienced a shift in the quadrant, while other provinces have shifted to quadrant III or I. Quadrant III is the densest quadrant, namely 14 provinces in 2013 consisting of Kep. Bangka Belitung, West Kalimantan, Central Kalimantan, North Sulawesi, Central Sulawesi, Southeast Sulawesi, West Sulawesi, North Maluku, Jambi, Bengkulu, Gorontalo, Maluku, West Papua, Papua. In 2017 it reduced to 13 provinces, namely Kep. Bangka Belitung, 
Kep. Riau, East Nusa Tenggara, West Kalimantan, Southeast Sulawesi, West Sulawesi, North Maluku, West Papua, Jambi, Bengkulu, Gorontalo, Maluku and Papua. Provinces located in quadrant III must be more concerned by the local government because there are few domestic tourist arrivals. In the period of 2013 and 2017, only Central Sulawesi province experienced a shift from quadrant 3 to quadrant 4 due to an increase in tourist arrivals.

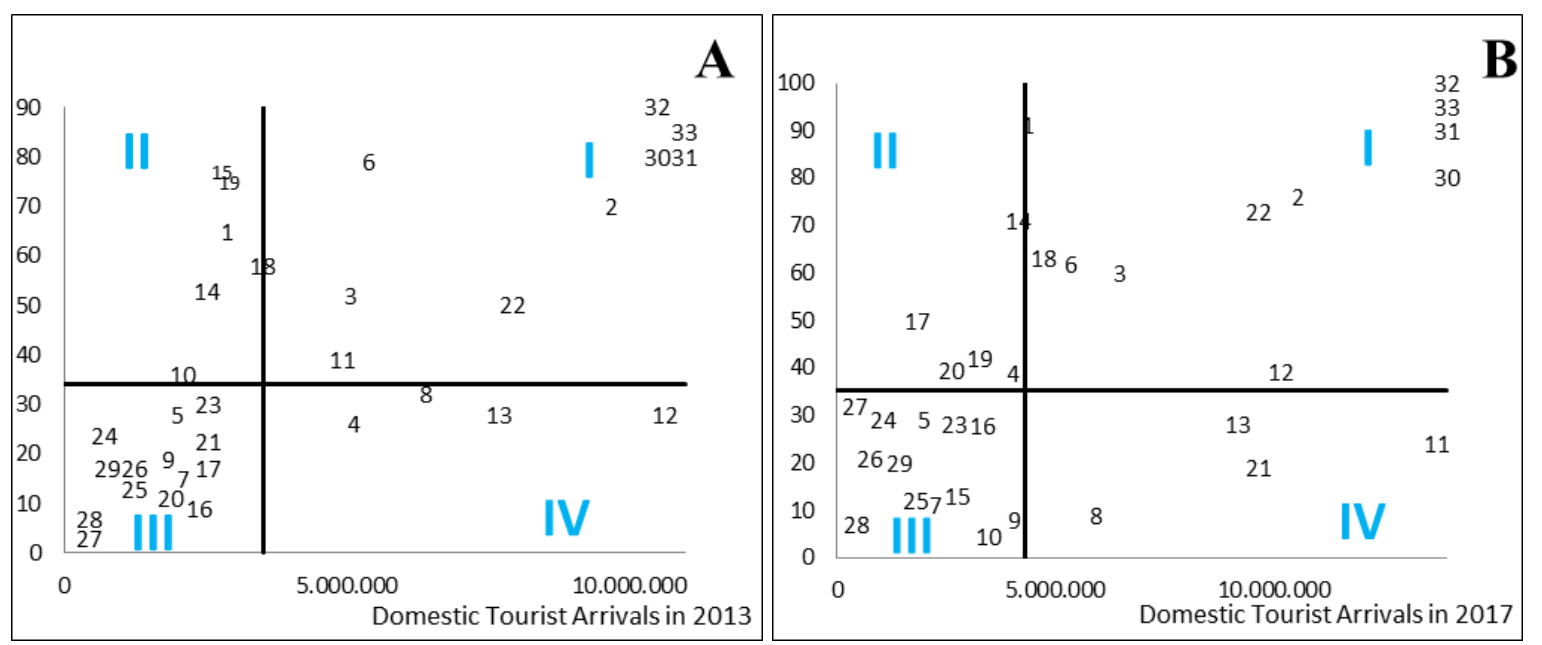

Figure 5 Relationship between domestic tourist arrival and frequency of disasters

\begin{tabular}{|c|c|c|c|c|}
\hline Kuadran & \multicolumn{2}{|c|}{2013} & \multicolumn{2}{|c|}{2017} \\
\hline I & $\begin{array}{l}\text { North Sumatera (2) } \\
\text { West Sumatera (3) } \\
\text { South Sumatera (6) } \\
\text { DI Yogyakarta (11) } \\
\text { South Sulawesi (22) }\end{array}$ & $\begin{array}{l}\text { DKI Jakarta (30) } \\
\text { West Java (31) } \\
\text { Central Java (32) } \\
\text { East Java (33) }\end{array}$ & $\begin{array}{l}\text { Aceh (1) } \\
\text { North Sumatera (2) } \\
\text { West Sumatera (3) } \\
\text { South Sumatera (6) } \\
\text { South Kalimantan (18) } \\
\text { South Sulawesi (22) }\end{array}$ & $\begin{array}{l}\text { Banten (12) } \\
\text { DKI Jakarta (30) } \\
\text { West Java (31) } \\
\text { Central Java (32) } \\
\text { East Java (33) }\end{array}$ \\
\hline II & $\begin{array}{l}\text { West Nusa Tenggara (14) } \\
\text { East Nusa Tenggara (15) } \\
\text { South Kalimantan (18) } \\
\end{array}$ & $\begin{array}{l}\text { Aceh (1) } \\
\text { Kep. Riau (10) } \\
\text { East Kalimantan (19) } \\
\end{array}$ & $\begin{array}{l}\text { West Nusa Tenggara (14) } \\
\text { Central Kalimantan (17) } \\
\text { East Kalimantan (19) }\end{array}$ & $\begin{array}{l}\text { Riau (4) } \\
\text { North Sulawesi (20) }\end{array}$ \\
\hline III & $\begin{array}{l}\text { Kep.Bangka Belitung (9) } \\
\text { West Kalimantan (16) } \\
\text { Central Kalimantan (17) } \\
\text { North Sulawesi (20) } \\
\text { Central Sulawesi (21) } \\
\text { South East Sulawesi (23) } \\
\text { West Sulawesi (25) } \\
\text { North Maluku (27) }\end{array}$ & $\begin{array}{l}\text { Jambi (5) } \\
\text { Bengkulu (7) } \\
\text { Gorontalo (24) } \\
\text { Maluku (26) } \\
\text { West Papua (28) } \\
\text { Papua (29) }\end{array}$ & $\begin{array}{l}\text { Kep.Bangka Belitung (9) } \\
\text { Kep. Riau (10) } \\
\text { East Nusa Tenggara (15) } \\
\text { West Kalimantan (16) } \\
\text { South East Sulawesi (23) } \\
\text { West Sulawesi (25) } \\
\text { North Maluku (27) } \\
\text { West Papua (28) }\end{array}$ & $\begin{array}{l}\text { Jambi (5) } \\
\text { Bengkulu (7) } \\
\text { Gorontalo (24) } \\
\text { Maluku (26) } \\
\text { Papua (29) }\end{array}$ \\
\hline IV & $\begin{array}{l}\text { Riau (4) } \\
\text { Lampung (8) } \\
\text { Banten (12) } \\
\text { Bali (13) } \\
\end{array}$ & & $\begin{array}{l}\text { Lampung (8) } \\
\text { DI Yogyakarta (11) } \\
\text { Bali (13) } \\
\text { Central Sulawesi (21) }\end{array}$ & \\
\hline
\end{tabular}

Quadrant IV is provinces that have low frequency of disasters and high domestic tourist arrivals. In 2013 there were 4 provinces, namely Riau, Lampung, Banten and Bali. In 2017 there were also 4 provinces namely Lampung, DI Yogyakarta, Bali and Central Sulawesi. Riau Province in 2017 shifted to quadrant II because it experienced an increase in the frequency of disasters and a decline in domestic tourist arrivals. Banten Province in 2017 shifted to quadrant $I$ due to an increase in the frequency of disasters but also experienced a decline in visits by domestic tourists.

Provinces that have priority tourism destinations are spread in quadrants I, II and III (Figure 5). Quadrant I consisted of the provinces of Central Java, DKI Jakarta, East Java, North Sumatra, and Banten. Quadrant III consisted of Kep. Bangka Belitung Province, East Nusa Tenggara, Southeast Sulawesi, and North Maluku. Quadrant II only West Nusa Tenggara Province. The priority destination provinces located in 
quadrants II and III indicate that the promotion in priority tourism destination is still not optimal so that domestic tourist arrivals are still low below the annual average. In addition, infrastructure development in the form of access to tourist attractions must be increased in order to facilitate domestic tourists.

\section{CONCLUSION}

Factors that influence domestic tourist arrivals in 33 provinces in Indonesia are fatality, GRDP/capita, CPI, population, hotel rooms, and accessibility. Disaster frequency variable is not significant or does not affect domestic tourist arrivals. Variables of GRDP/capita, CPI, population, hotel rooms, and accessibility have a positive influence on domestic tourist arrivals, while fatality variable has a negative effect on domestic tourist arrivals. The biggest influence is the population variable and GRDP/capita, while the smallest influence is the fatality variable.

From the discussion that has been done, the suggestions put forward on fatality variable that has a negative effect on domestic tourist arrivals. Therefore, the awareness of the disaster must be improved so that it can reduce fatalities due to disaster. The population has the greatest result so that promotion to provinces that have large population can increase domestic tourist arrivals. GRDP/capita must be encouraged to create man-made tourist attractions such as culinary tourism, shopping tourism, selfie tourism, health tourism, theme park and others. For the private sector, investment in the hotel sector can be increased in order to increase domestic tourist arrivals.

\section{Acknowledgement: None}

Conflict of Interest: None

Source of Funding: None

\section{REFERENCES}

1. Badan Nasional Penanggulangan Bencana. Data Informasi Bencana Indonesia (DIBI). Jakarta: Indonesia. Available From: https://bnpb.cloud/dibi/

2. Brida J. G., Risso W. A. Tourism as a factor of long-run economic growth: an empirical analysis for Chile. European Journal of Tourism Research. 2009; 2(2):178-185.

3. Cro S., Martins A. M. Structural Breaks in International Tourism Demand: Are They Caused by Crises or Disasters? Tourism Management. 2017; 63:3-9. doi: 10.1016/j.tourman.2017.05.009.

4. Dogru T., Bulut U. Is Tourism an Engine for Economic Recovery? Theory an Empirical Evidence. Tourism Management. 2017; 1-10. doi: 10.1016/j.tourman.2017.06.014.

5. Guo J., Liu H., Wu X., Gu J., Song S., Tang Y. Natural Disasters, Economic Growth and Sustainable Development in China - An Empirical Study Using Provincial Panel data. 2015; 7: 16783 - 16800. doi:10.3390/su71215847.

6. Hafiz M., Harun M. F., Jamaluddin M. R. Trade and Tourism Demand : A Case of Malaysia. IACSIT Press. 2010; 1:1-4.

7. Jitpraphai S. M., Arunotai N., Tiangtrong A. Tsunami Disaster Risk and Vulnerability in Coastal Tourism Community: The Case of Khao Lak Area, Thailand. Tourism in Marine Enviroments. 2017; 12(3-4):155167.

doi:10.3727/154427317X15022384101333

8. Kementerian Pariwisata. Neraca Satelit Pariwisata Nasional 2 2016. Jakarta: Indonesia. 2017.

9. Kementerian Pariwisata. Kajian Data Pasar Wisatawan Nusantara 2017. Jakarta: Indonesia. 2017.

10. Khazai B., Mahdavian F., Platt, S. Tourism Recovery Scorecard (TOURS) Benchmarking and Monitoring Progress on Disaster Recovery in Tourism Destinations. International Journal of Disaster Risk Reduction. 2017; 27:75-84. doi:10.1016/j.ijdrr.2017.09039.

11. Kusni A., Kadir N., Nayan S. International Tourism Demand in Malaysia by Tourist from OECD Countries: A Panel Data Econometric Analysis. Science Direct. 2013; 7:28-34. doi: 10.1016/S22125671(13)00214-1. 
12. Laws E. and Prideaux B. Tourism Crises: Management Responses and Theoritical Insight. New York: The Haworth Hospitality Press. 2005.

13. Liu A., Wu D. C. Tourism Productivity and Economic Growth. Annals of Tourism Research. 2019; 76:253-265. doi: 10.1016/j.annals.2019.04.005.

14. Masinde B., Buigut, S. Effect of Tourism and Travel Warning on Kenyan Tourism Demand. Tourism Analysis. 2018; 23:283288. doi: 10.3727/108354218X15210313771322.

15. Mukherjee S., Hastak M. A Novel Methodological Approach to Estimate the Impact of Natural Hazard-Induced Disasters on Country/Region-Level Economic Growth. Int J Disaster Risk Sci. 2018; 9:7485. doi:10.1007/s13753-017-0156-3.

16. Padli J., Ahmad N., Nawawi M. N. The Impact of Natural Disasters, Technological Change and Education on Poverty Rate : Evidence from Developing Countries. Jurnal Ekonomi Malaysia. 2018; 53(2):21 28. doi: 10.17576/JEM-2019-5302-2.

17. Ritchie B. W. Tourism Disaster Planning and Management: From Response and Recovery to Reduction and Readiness. Current Issues in Tourism. 2008; 11(4): 315-348. doi:10.1080/13683500802140372.

18. Sahara N. Analisis Daya Saing dan FaktorFaktor yang Memengaruhi Permintaan Pariwisata Indonesia : Sepuluh Negara Utama Asal Wisatawan. Bogor: Institut Pertanian Bogor; 2017.

19. Samitas A., Asteriou D., Polyzos S., Kenourgios D. Terrorist Incidents and Tourism Demand : Evidence from Greece. 2018: 25:23-28. doi: 10.1016/j.tmp.2017.10.005.

20. Shahzad S. J. H., Shahbaz M., Ferree R., Kumar R. R. Tourism-led growth hypothesis in the top ten tourist destinations: New evidence using the quantile-onquantile approach. Tourism management.
2017; 60:223-232. doi: 10.1016/j.tourman.2016.12.006.

21. Skidmore M., Toya, H. Economic Development and the Impacts of Natural Disasters. Economic Letters. 2007; 94:2025.

22. Som A. P. M., Ooi C. A., Hooy C. W. Crisis Typologies and Tourism Demand. AnatoliaAn International Journal of Tourism and Hospitality Research. 2014; 25(2): 302-304. doi:10.1080/13032917.2013.876549.

23. Sun J., Zhang J., Ma J., Zhang Y. Total Factor Productivity assessment of tourism industry: Evidence of China. Asia Pacific Journal of Tourism Research. 2015; 20(3): 280-294. doi: 10.1080/10941665.2013.877047.

24. Tang C. F., Tan E. C. How stable is the tourism-led growth hypothesis in Malaysia? Evidence from disaggregrated tourism markets. Tourism Management. 2013; 37:52-57.

25. Vu T. B., Im E. I., Thompson R. R., DeWitt T. The Interaction of Tourism and Cyclone Activity in East Asia : Sustainability and Disasters. Tourism Review International. 2017; 21:379-393. doi:10.3727/154427217X15094520591358

26. Webster C., Ivanov S. Transforming competitiveness into economic benefits: Does tourism stimulate economic growth in mpre competitive destinations?. Tourism Management. 2014; 40: 137-140. doi: 10.1016/j.tourman.2013.06.003.

27. Wu L., Walters G. Chinese Travel Behaviour in Response to Disastrous Events: The Case of the Japan Earthquake. Journal of China Tourism Research. 2016; 12(2): 216-231. doi: 10.1080/19388160.2016.1197870.

How to cite this article: Asmara A, Uzdah AH. Disasters and domestic tourist arrivals in Indonesia in 2013-2017. International Journal of Research and Review. 2021; 8(10): 465-477. DOI: https://doi.org/10.52403/ijrr.20211061 